\title{
Pertvarkyta lyderystè:
} kaip Ukrainos krizė ir Krymo aneksija ¡tvirtino vadovaujamą Vokietijos vaidmeni ES užsienio politikoje

Nesena egzistencinių krizių Europoje virtinè - ekonomikos krizè, Rusijos agresija Ukrainoje ir 2015 m. pabėgèlių krizè - baigèsi sukurdama naują varomąją jègą Europos Sąjungoje. Vokietija tapo, vargu ar ginčijama, pagrindinè sprendimų priemèja. Kaip tik dèl krizès Ukrainoje ir Rusijai aneksavus Krymą 2014 m., Vokietija taip pat prisiemė vadovaujamą vaidmenį, kurio ji ilgai vengé, Europos Sajungos užsienio politikos srityje. Tačiau Berlynui šis naujas vaidmuo nèra savaime suprantamas - tik palaipsniui Vokietija èmè apsiprasti su tokiu svarbiu vaidmeniu, kuris atsirado daugiau dèl išorinių aplinkybių negu dèl vidinių sumanymų. Savo ịvaizdžio užsienyje suvokimas, vis dar vyraujantis kaltės jausmas baimè būti suprastai kaip dominuoti siekiančia valstybe trukdè Vokietijai iki šiol užimti pagrindines pozicijas politinèje arenoje. Ji mieliau slapta dare ịtaką, pateikdama save kaip "pagrindinę padedančią Europai pareigūnę "1. Šis straipsnis analizuoja, kaip Vokietija nors ir nenoriai, bet įsitvirtino (ypač dèl $2014 \mathrm{~m}$. prasidejusios Ukrainos krizès) kaip pagrindinè sprendimų prièmèja Europos Sąungos bendroje užsienio ir saugumo politikoje ir tapo de facto vadovaujančia šalimi rengiant atsaką Rusijai. Straipsnyje aptariami šio naujojo vaidmens vidaus ir išorès padariniai ir ypač jo poveikis Baltijos valstybèms.

\section{Ivadas}

Rusijos įvykdyta Krymo aneksija 2014 m. kovo mènesị ir destabilizuojantis Rusijos vaidmuo Rytų Ukrainoje sugriovè ES iliuziją, kad Europa įsitvirtino postmoderniame pasaulyje, o kariniai konfliktai ir teritorijų užgrobimai esti tik istorijos knygose. Paskutinijji dešimtmetị ES kūre savo užsienio politiką remdamasi prielaida, kad, išnykus klasikinèms karinėms grėsmėms, iššǔkiai saugumui kils iš nevalstybinių veikejjų: teroristų, žlugusių valstybių, organi-

\footnotetext{
* Wolfgang Koeth - Europos viešojo administravimo instituto (Mastrichtas, Nyderlandai) vyresnysis lektorius. Adresas korespondencijai: P.O. Box 1229, 6201 BE Maastricht, the Netherlands; tel. +31 433296 338, el. p.: w.koeth@eipa.eu

${ }^{1}$ German Missions in the United States, "Foreign Minister Steinmeier Travels to Washington", Atlanta, March 16, 2015, http://www.germany.info/Vertretung/usa/en/__pr/P_Wash/2015/03/11-SteinmeierUSA.html, March 14, 2016.
} 
zuoto nusikalstamumo ar Balkanų tipo regioninių konfliktų ${ }^{2}$. Briuselis apskritai manė, kad XXI amžiuje užsienio politika grindžiama normų ir vertybių perdavimu ${ }^{3}$ užsieniui, o ne karinès jègos panaudojimu. Isitikinimas, kad šis postmodernios politikos požiūris taip pat galès transformuoti buvusias Sovietų Sajungos respublikas ị modernias Europos valstybes, buvo pagrindinė paskata pasirašyti ES ir Ukrainos, Gruzijos, Moldovos asociacijos sutartis 2014 metais.

Pagal savo pokarines pacifistines tradicijas, Vokietija ${ }^{4}$ yra stipri taisyklèmis grindžiamos daugiašalès užsienio politikos propaguotoja. Pačios Vokietijos užsienio politiką charakterizuoja jos kaip civilinès galybės vaidmuo ir jos Rytų politika t. y. specialūs santykiai su buvusiomis Sovietų Sąjungos bloko šalimis. Be to, specialūs Vokietijos ir Rusijos santykiai buvo svarbūs Vokietijai ne vien tik ekonomine, bet taip pat ir politine prasme, kadangi jie didino Berlyno svarbą ir ES, ir NATO. Todèl Krymo aneksija ir menkai užmaskuota Maskvos agresija Rytų Ukrainoje turèjo dideli poveikį Vokietijos užsienio politikai. Tai ne tik paskatino Berlyną persvarstyti savo santykių su Maskva pobūdị, bet taip pat pakeitè dinamiką Europos Sąjungoje, kurioje Vokietija jautėsi atliekanti vadovaujamą vaidmení, nors šis atsirado veikiau atsitiktinai nei dèl sąmoningo Vokietijos siekio. Ši Vokietijos kaip aktyvaus veikejjo ES užsienio politikoje emancipacija jau pastebima Kosove ir Afganistane nuo tada, kai Helmuto Kohlio vyriausybę pakeitė socialdemokratų ir žaliųjų koalicija 1998 m. Nors ir nesiekęs vadovaujamo vaidmens, Berlynas daugiau jo ir nevengè, tokiu būdu tarsi atsitiktinai užimdamas vadovaujamą poziciją ${ }^{5}$.

Šis straipsnis analizuoja, kaip Vokietija (ypač per Ukrainos krizę, prasidejusią $2014 \mathrm{~m}$.) įsitvirtino (nors nenoriai) kaip pagrindinè sprendimų prièmejja ES bendroje užsienio ir saugumo politikoje (BUSP) ir tapo de facto vadovaujančiaja šalimi, formuojant ES atsaką Rusijai. Toliau bus nurodyti šio naujojo vaidmens vidaus ir išorès padariniai, taip pat aptarta įtaka kitoms

\footnotetext{
${ }^{2}$ European Security Strategy, 2003.

${ }^{3}$ ES normas ir vertybes apibrèžia Europos Sąjungos sutarties (Lisabonos redakcija) 2-asis straipsnis: „Sajunga yra grindžiama šiomis vertybėmis: pagarba žmogaus orumui, laisve, demokratija, lygybe, teisine valstybe ir pagarba žmogaus teisèms, įskaitant mažumoms priklausančių asmenų teises. Šios vertybès yra bendros valstybėms narėms, gyvenančioms visuomenejje, kurioje vyrauja pliuralizmas, nediskriminavimas, tolerancija, teisingumas, solidarumas ir moterų bei vyrų lygybe்.“

${ }^{4}$ Šiame straipsnyje kalbant apie 1949-1989 m. laikotarpị terminai „Vokietija“ ir „Vokietijos užsienio politika" siejami su Vokietijos Federacinès Respublikos (Vakarų Vokietijos) užsienio politika, kuri vèliau tapo 1990 m. suvienytos Vokietijos užsienio politikos modeliu. Buvusios Vokietijos Demokratinès Respublikos (Rytų Vokietijos) užsienio politika turejo menką autonomiją, nes ją esmingai ribojo ir kontroliavo Sovietų Sajunga.

${ }^{5}$ Nicolas Wright, “Germany and the CFSP: The accidental leader?", Paper prepared for the 37th Annual Conference of the International Association for the Study of German Politics, London, 16th-17th May, 2011.
} 
politikos sritims ir ypač jo poveikis Baltijos valstybėms. Dèl to, mes turime pirmiausia panagrinèti Vokietijos užsienio politikos principus ir Vokietijos ir Rusijos santykių specifiką.

\section{Vokietijos užsienio politika, kylanti iš Šaltojo karo}

Atsitiktiniam stebètojui gali kartais būti sunku suprasti Vokietijos užsienio politikos varomąsias jègas. Kai dauguma šalių užsienio politiką suvokia kaip priemonę ginti savo politinius ir ekonominius interesus užsienyje veikiant kitas šalis, pastangos naudoti užsienio politiką kaip priemonę ịgyti įtakos pokarinejje Vokietijoje buvo tabu ištisus dešimtmečius ${ }^{6}$. Nors per pirmuosius dvidešimt VFR gyvavimo metų revizionistinès tendencijos vis dar pasireikšdavo, visiškas nacionalinès ideologijos atmetimas buvo viena iš pamatinių pokarinès Vakarų Vokietijos politikos atramų ${ }^{7}$. Dèl šio naujo požiūrio ị užsienio politiką (iš dalies skatinamo kaltès ir gèdos jausmo dèl nacizmo nusikaltimų, iš dalies dèl komunizmo plitimo baimès) iš politinio žodyno dingo „nacionalinis interesas" ir ,identitetas“.

Nesmagus Vokietijos santykis su praeitimi, pasikliovimas Vakarų sajungininkais ir reikmé naujai apibrèžti savo vietą Europoje ir pasaulyje pavertė šali Europos integracijos pradininke. Europos integracijos procesas suteike Vokietijos Federacinei Respublikai galimybę prisiimti naują vaidmenį, kuris atitiktų jos ekonominius interesus (galimybe jos pramonès produktams patekti ị bendrąją rinką). Šis troškimas puikiausiai derèjo su Vokietijos kaimynių noru varžyti Vokietiją per supranacionalinị bendradarbiavimo mechanizmą, kuris neleistu jai vèl pasukti ypatingu keliu (vok. Sonderweg), ir leido joms turèti naudos iš Vokietijos pramonès dinamikos. Tokiu būdu VFR tapo Europos integracijos reklamos afiša: teigiamas ir produktyvus Vokietijos vaidmuo tarptautinëje politikoje pasireiške vien tik Europoje.

Kol Vokietijos euroatlantinè integracija pasirodè esanti vienodai naudinga ir Vokietijai, ir jos sąungininkèms, kaip tik santykiai su Sovietų Sąjunga ir Rytų bloko šalimis 1960-aisiais ir 1970-aisiais tapo Vakarų Vokietijos užsienio politikos išbandymu. Geopolitinė Vokietijos situacija reikalavo tam tikro pragmatizmo: Vokietijos padalijimas, daugybès vokiečių ryšiai su giminėmis

\footnotetext{
${ }^{6}$ Lisbeth Aggestam, “Germany” in Ian Manners, Richard Whitman, eds. (2000), The Foreign Policies of European Union Member States, Mancherster Universtity Press, p. 71.

${ }^{7}$ Kitos dvi atramos buvo euroatlantine integracija ir naujas patriotizmo apibūdinimas (vok. Verfassungspatriotismus, arba konstitucinis patriotizmas), kur lojalumas persikèlè iš etninès nacionalinès valstybès ị vertybių sistemą, išdėstytą pagrindiniame ịstatyme (vok. Grundgesetz).
} 
likusiais už geležinės uždangos ir Vakarų Berlyno klausimas reikalavo nuosaikių pragmatiškų santykių. Kanclerio Willy Brandto aštuntojo dešimtmečio pradžioje vykdyta Rytų politika (ją simbolizavo garsusis 1970 m. atsiklaupimas (vok. Kniefall) pagerbiant Varšuvos geto sukilimo aukas) buvo naudinga trigubai, nes palengvino žmonių bendravimą, atvèrè rinkas Vakarų Vokietijos pramonei ir leido užsiimti stiprią moralinę poziciją, palyginti su Rytų Vokietija, nes vienareikšmiškai Vakarų Vokietija prisiimè atsakomybę už praeitị.

Galimybè skatinti laisvę ir demokratiją ne vien tik savo, bet viso Vakarų pasaulio vardu, padejo Vokietijai dar labiau sustiprinti savo naują, postmodernų identitetą, pagrịstą daugiašališkumu ir švelniąja galia, kas ir šiandien yra Vokietijos politikos varomoji jega. Kai VDR žlugo 1989 m., magnetinè trauka Vakarų Vokietijos modelio, jungiančio ekonominę gerovę su demokratija ir teisètvarka, moraliniu pranašumu ir teigiama tarptautine reputacija, tapo jejga, kuriai Rytų vokiečiai negalejo atsispirti.

\section{Vokietija ir BUSP: lèta Vokietijos užsienio politikos emancipacija Europos kontekste}

1990 m. „2 + 4“ susitarimas galutinai išardè senąją Šaltojo karo tvarką ir atstatė Vokietijos suverenitetą taip pat ir užsienio politikoje. Pradinès Vokietijos Vakarų partnerių baimès dèl suvienytos Vokietijos hegemonijos Europoje (ypač po to, kai Vokietija nesuderinusi pozicijos 1991 m. pripažino Kroatiją ir Slovèniją) baigèsi $1993 \mathrm{~m}$. Mastrichto sutartimi ES bendrosios užsienio ir saugumo politikos (BUSP) ịkūrimu. BUSP buvo apibūdinama kaip svarbus diplomatinis projektas, kuris turejo ịvesti galių pusiausvyrą ir ịterpti padidejusią Vokietijos valstybę i vis labiau besivienijančią Europą ${ }^{8}$. Be to, šiuo didelių geopolitinių pasikeitimų laikotarpiu, kai Europa susigadino reputaciją savo veiksmais kilus Persų ilankos ir Jugoslavijos krizems, BUSP buvo suvokiama kaip įrankis, stiprinsiantis Europos identitetą9

Ispūdinga, kad rengiant Mastrichto sutartị Vokietija buvo viena iš valstybių, kurios palaikè supranacionalinę BUSP, kad sprendimai galètų būti priimami balsuojant kvalifikuotajai daugumai (dèl to būtų atisakyta nacionalinio veto teisès) ir aktyviau dalyvaujant Europos Parlamentui, t. y. pasiūlymus, ku-

\footnotetext{
${ }^{8}$ Stephan Keukeleire, Tom Delreux (2014), The Foreign Policy of the European Union, Palgrave, p. 46.

${ }^{9}$ Ibid, p. 47.
} 
riuos griežtai atmetė kiti du svarbūs užsienio politikos veikejai Jungtinė Karalystė (JK) ir Prancūzija. Žiūrint iš šalies, galëjo pasirodyti, kad Vokietija, prisijungdama prie BUSP, sumažino nacionalinès politikos veikimo erdvę. Tačiau kaip tik Vokietijos užsienio politikos perkèlimas į BUSP igalino ją išsivaduoti kaip užsienio politikos veikèją ES struktūros viduje.

Bet buvimas Europos politikos struktūros dalimi apsunkino Vokietijos galimybes laikytis ankstesnès politinės atsakomybès vengimo politikos vadovaujantis vadinamąja čekių knygelès diplomatija (vok. Scheckbuchdiplomatie), kurios esmè buvo finansiškai remti kitų ES partnerių veiksmus, pačiai išliekant nuošalyje. Politinès atsakomybės prisiemimas reikalavo, kad Vokietija nebesivadovautų vengimo ir karinio nesikišimo politika (kuria buvo remiamasi $1991 \mathrm{~m}$. Persu ịlankos kare arba pirmuose dviejuose Balkanų karuose).

Tai nebuvo neginčytina. Kai Vokietijos kariai pradèjo dalyvauti tarptautinèse taikos palaikymo misijose dešimtajame dešimtmetyje, tam tikra Vokietijos politikų dalis ịspejo apie gèdingą grịžimą prie militarizmo, kuris pakurstytų naujo Vokietijos hegemonizmo ir imperializmo baimes. Apie šias baimes buvo kalbama labiau pačioje Vokietijoje negu už jos ribų. Kaip tik Kosove 1999 m. Vokietija sugebejjo galutinai atsikratyti baimès, nulemtos istorijos, ir pripažinti, kad jos karinis įsikišimas (kartu su JAV vadovaujama koalicija) yra pateisinamas vykdant po karo priimtą ịsipareigojimą niekada neleisti vykti genocidui ar kurtis koncentracijos stovykloms.

Baimé, kad Vokietija atsisakys dalyvauti Europos projekte ieškant ypatingo kelio (vok. Sonderweg), pasirodè esanti nepagrịsta - Kohlio vyriausybè, kurioje vyravo politikų kartos, paveiktos fašizmo ir Antrojo pasaulinio karo patirties, atstovai, buvo visa širdimi atsidavusi Europos projektui ir jaute antipatiją bet kokioms vokiečiu pastangoms dominuoti. Greičiau jau Vokietijos ekonominė galia, demografija ir geografinè padètis vertė ją tapti Europos galios centru. Šis vaidmuo, kuris tapo labai akivaizdus prasidejus ir tęsiantis $2008 \mathrm{~m}$. finansų krizei, buvo ne tik pripažintas, bet aktyviai remiamas daugelio Vidurio ir Rytų Europos kaimynių. Šių šalių požiūrị geriausiai išreiške Lenkijos užsienio reikalų ministras Radosławas Sikorskis, kai 2011 m. finansų krizès kontekste jis viešai pareiškè: „Aš bijau Vokietijos galios mažiau nei jos neveiklumo" ${ }^{10}$.

ES viduje artima Vokietijos partnerystè su Prancūzija sudarè sąlygas šaliai išlikti nuošalyje ir tuo pat metu aktyviai formuoti ES politiką pagal savo interesus. Svarbios iniciatyvos (kaip ekonomikos ir pinigų sajunga) buvo rengiamos

\footnotetext{
${ }^{10}$ Radek Sikorski, "I fear German power less than I am beginning to fear German inactivity", Financial Times, 28 November 2011.
} 
artimai bendradarbiaujant ir po to pateikiamos kaip bendras sumanymas. Tai atitiko Prancūzijos norą didinti, o Vokietijos mažinti savo, kaip varomosios jègos, stovinčios už Europos politikos darbotvarkès formavimo, profili. Bet Berlyno ir Paryžiaus interesai ne visada sutapo - plètros procesas, prasidèjęs antrojoje $\mathrm{XX}$ a. dešimtojo dešimtmečio pusèje (ir pasiekęs kulminaciją prisijungus dar 10 Vidurio ir Rytų Europos valstybių 2004 m.) buvo, visų pirma, energingai remiamas Vokietijos, siekiančios, kad Rytų kaimynystėje būtų stabilu, ir norinčios, kad ES rinka pasiektų Europos rytus. Paryžius plètrą laikè grèsme glaudesnei politinei sąjungai ir traktavo kaip prancūzų ir vokiečių lyderiavimo ES silpnèjimą.

BUSP viduje specialūs santykiai su Rusija pasirodè esą svarbūs Vokietijai ne vien tik ekonomine, bet taip pat ir politine prasme. Visų pirma, šie santykiai turẻjo didelę simbolinę reikšmę, nes būtent Rusija labiausiai nukentėjo nuo vokiečių Antrajame pasauliniame kare. Geri santykiai su Rusija Vokietijai reiškè apsivalymą nuo militaristinès praeities. Be to, dèl šių ryšių Vokietija tapo svarbesne Europos Sajungoje ir NATO neturèdama didelés karinès jẻgos. Todèl Europa visiškai natūraliai pradejo orientuotis i Vokietiją, jau atliekančią vadovaujamą vaidmeni po $2008 \mathrm{~m}$. finansų krizès ir po Rusijos įvykdytos Krymo aneksijos. Vèlgi, bandant tinkamai ịvertinti Berlyno poziciją Ukrainos krizès atžvilgiu, reikètų apžvelgti Vokietijos ir Rusijos santykių istoriją.

\section{Vokietijos ir Rusijos santykių išskirtinumas}

Ištisus amžius Vokietija ir Rusija vaidino svarbų vaidmenị viena kitos atžvilgiu. Visų pirma, abi šalys turi daug panašumų: abi šalys, neturẻdamos natūralių sienų, išsiplètė savo kaimynių laisvès ir suvereniteto kaina, siekdamos padidinti savo ịtaką ir galiąa ${ }^{11}$, abi šalys ne kartą bendradarbiavo pasirašydamos susitarimus, tokius kaip Rapalo sutartis arba Molotovo-Ribentropo paktas, turëjusius didžiuli poveikị tarptautiniu mastu. XX amžiuje abi šalys ideologiškai teisino savo imperialistinius siekius, kuriuos vèliau sužlugdè išorinès aplinkybès. Abiejų šalių naujas nacionalinio identiteto apibrèžimas gali būti grindžamas jų praeitimi, bet Vokietija sugebejjo igyti naują postmodernų identitetą, visiškai nutraukdama ryšius su praeitimi, o Rusija nuejo priešingu keliu atsigrę̌ždama ị šlovingą praeitị.

Istorinè kaltè, dèkingumas Rusijai, sudariusiai galimybę Vokietijai susivienyti ir išvedusiai karius, drauge su Vokietijos ekonominiais interesais galè-

\footnotetext{
${ }^{11}$ Angela Stent (2000), Russia and Germany Reborn: Unification, the Soviet Collapse, and the New Europe, Princeton University Press.
} 
tų paaiškinti, kodèl Vokietija buvo laikoma viena iš uoliausių Rusijos rèmëjų dešimtojo XX a. dešimtmečio pradžioje. O Rusija (kaip ir kitos posovietinès valstybès) susidūrè su gilia ekonomine ir socialine krize. Vokietijoje Sovietų Sąjungos žlugimas, Vidurio ir Rytų Europos tautų emancipacija buvo siejami su Francis Fukuyamos knyga „Istorijos pabaiga“, kurioje europietiškos vertybès demokratija ir žmogaus teisès turejo būti tokios pat nuo Lisabonos iki Vladivostoko.

Bet Vokietija nepakankamai įvertino daugelio rusų, kurie buvo labiau linkę kęsti dramatišką gyvenimo lygio pablogèjimą negu pasinaudoti dèl Šaltojo karo baigties atsiradusiomis geopolitinèmis privilegijomis, pažeminimo jausmą. Mąstymo nesuderinamumą simbolizavo Michailas Gorbačiovas, kuris Vokietijoje iggavo vos ne popžvaigždès statusą ${ }^{12}$, bet buvo niekinamas Rusijoje dèl to, jog nusmukdè gyvenimo lygị ir pažemino tautą, kuri per mažiau nei dešimtmetị iš baimę keliančios supervalstybès virto gailestị keliančia humanitarinès pagalbos gavej ${ }^{13}$.

Vladimiro Putino, jauno KGB pareigūno, dirbusio Drezdene tuo metu, kai žlugo VDR, išrinkimas Rusijos prezidentu 2000 m., sutapo su žaliavų, ypač dujų ir naftos, kurias ji gausiai eksportavo, kainų kilimu. Tai labai pagerino rusų gyvenimo kokybę. NATO ir ES plètra $2004 \mathrm{~m}$. buvo labai nenoriai priimta Rusijos, kuri neturejo priemonių plètrai sustabdyti, kadangi ji vis dar buvo issivèlusi i antrajji karą Čečènijoje ir kitus tarptautinius konfliktus. Rusija taip pat neprisidèjo prie ES Europos kaimynystès politikos iniciatyvos, kuri turëjo išplèsti jos ịtaką. Rusija atsisakè būti tiesiog ES užsienio politikos objektu.

Putinas niekada neslèpè ignoruojąs ES ir teikiąs pirmenybę principui „skaldyk ir valdyk“, kurio esmè buvo potencialių skirtumų tarp valstybių narių išnaudojimas. Putinas priminè Vokietijai, kad Rusija rèmé ir prisidèjo prie Vokietijos susivienijimo proceso priešinantis Prancūzijai ir Jungtinei Karalystei. Šiuo požiūriu, Nord Stream dujotekio, tiekiančio Rusijos dujas tiesiai ị Vokietiją apeinant Baltijos valstybes ir Lenkiją, nutiesimas tapo vienu iš pagrindinių strateginių Rusijos laimejjimų.

Kai 2005 m. Angela Merkel tapo Vokietijos kanclere ir pakeitė Gerhardą Schröderį, Rusijos ir Vokietijos lyderių santykiai iš esmès pasikeitè. Schröderis, kuris kartą apibūdino Putiną kaip krištolo skaidrumo demokratą, buvo

\footnotetext{
${ }^{12}$ Nors dèl skirtingų priežasčių: kai daugelis kairiụjų vokiečių jị laikè socializmo reformatoriumi, dešinieji (ir Rytų Vokietijoje) džiaugsmingai sveikino jị už Sovietų Sąjungos demontavimą ir galimybę suvienyti Vokietiją.

${ }^{13}$ Europos Bendrijos viršūnių susitikime Mastrichte 1991 m. gruodžio mèn. valstybès narès ne tik aptarè Mastrichto sutartí, kuri po dviejų metų dave pradžią ES, bet ir aptare klausimą dèl maisto tiekimo situacijos Maskvoje ir Sankt Peterburge.
} 
išplètojęs stiprią vyrišką draugystę (Männerfreundschaft) su Putinu. Tačiau Merkel, užaugusi buvusioje VDR ir žinodama autoritarinès valdžios mechanizmus iš vidaus, daug mažiau nei Schröderis pasidave Putino kerams. Vis tik būdama viena iš stambių Vokietijos prekybos partnerių ${ }^{14}$ ir atitinkamai Vokietijos ekonominès diplomatijos tradicijų, Rusija liko svarbi formuojant Vokietijos užsienio politiką. Tai atspindi septintojo dešimtmečio pabaigos tuometinio Vokietijos kanclerio Willy Brandto pradètą Wandel durch Annäherung politiką, kurios esmė buvo siekis pokyčių žingsnis po žingsnio pirmiausiai mažinti ittampą kasdieninio bendradarbiavimo klausimuose.

Visu krizès Ukrainoje laikotarpiu Merkel siekė glaudaus bendradarbiavimo su Europos partneriais. Nors ryžtingai atmesdama bet kokius siūlymus dèl Ukrainos prisijungimo prie ES perspektyvos (labai nepopuliarios politinèje darbotvarkejje), Vokietija tvirtai rèmė ES asociacijos sutartị su Ukraina, kaip pagrindą glaudesnei integracijai. Europos Sąjungai (ir Vokietijai) asociacijos sutartis buvo sumanyta kaip priemone skleisti europines normas ir vertybes, tokias kaip demokratija, teisès viršenybė, laisvosios rinkos ekonomika. Tokia sutartis nekèlè prieštaravimų, nes nevaržè partnerių valios ir politikos.

Bet šis požiūris, atsiradęs tuo metu, kai ES buvo vienintelis integracijos modelis Europos žemyne, dabar susidūrè su Rusijos planais ịkurti Eurazijos (ekonominę) Sąungą. Todèl tos paprastos minties, kad kita valstybè ne tik galètų pasipriešinti jos planams, bet ir atvirai bandytų mesti jiems iššūkị, nevengdama karinio konflikto, nebuvo galima įsivaizduoti iki pat $2014 \mathrm{~m}$. kovo mèn. Tačiau priešingai nei ES, Rusija dar nèra postmoderni. Ji savo interesus suvokia labiau per XX amžiaus pirmosios pusès nulinès sumos žaidimo realistinès politikos prizmę, kur geopolitinè ịtaka pasireiškia kaip karinès ir ekonominès galios pasekmé. Tai jau buvo akivaizdu, kai Rusija ịsiveržè i Gruziją 2008 m., nors tuo metu tai ne visi pripažino. Taigi Rusija interpretavo asociacijos sutarties pasirašymą kaip tiesioginị iššūkị savo politiniams siekiams, kurie reikalavo griežto atsako.

Nors iki 2008 m. Rusija prisistatydavo kaip sienų neliečiamumo ir nacionalinio suverenumo gynejja ${ }^{15}$, pati šių principu èmé nesilaikyti jau 2008 m. Pietų Osetijoje ir Abchazijoje. Atmetusi bet kokius teritorinio vientisumo ir sienų neliečiamumo principus, ji nurode i vienašališką Kosovo nepriklausomybés deklaraciją, pripažintą Vokietijos ir kitų 23 ES šalių narių, kaip jos

\footnotetext{
${ }^{14}$ Rusija yra 11-ta didžiausia Vokietijos prekybos partnerè. 2013 m. Vokietija eksportavo ị Rusiją prekių ir paslaugų už 23 milijardus eurų.

${ }^{15}$ Rusija dažnai deklaravo šiuos principus, atsisakydama patvirtinti 2007 m. JT vadovaujamą Ahtisaari planą, skirtą apibrèžti Kosovo statusą, kadangi jis pažeistų Serbijos teises ị suverenitetą ir teritorini vientisumą.
} 
veiksmus pateisinantị precedentą ir karine jẻga rẻmė Abchazijos ir Pietų Osetijos atsiskyrimą, savo veiksmus pagrịsdama piliečių apsisprendimo teise ir tariamais žmogaus teisių pažeidimais (rusakalbių gyventojų).

Europos Sajungai nereaguojant i Abchazijos ir Pietų Osetijos de facto aneksiją $2008 \mathrm{~m}$., nepaisant keleto ES ir šalių narių diplomatinių protesto notų, ir tai, jog reikalai Berlyne ir Briuselyje greitai grịžo ị buvusias vèžes, leido Putinui manyti, kad Vakarai neišdrịs konfrontuoti su Rusija ir nesikiš.

\section{Vokietijos reakcija į Euromaidaną ir Krymo aneksiją}

Vokietijos kanclerė Merkel niekada nepasižymėjo drąsia politika. Jos visiškas nenoras rizikuoti ir ryžtingų veiksmų vengimas daugiau nei dešimtmeti vadovaujant Vokietijos vyriausybei, tapo savotiška etikete ${ }^{16}$. Politine prasme jos laukimas pasiteisino, nes ji pasieke rekordiškai aukštus reitingus viešosios nuomonès apklausose ir buvo dukart perrinkta. Jos pastangos laikytis nuošalyje, vykstant politiniams nesutarimams, leido kanclerei susikurti „Tautos motinos" ịvaizdị.

Vis dèlto vykstant Euromaidanui, kuris prasidejo 2013 m. pabaigoje ir pasiekè kulminaciją, kai iš šalies pabėgo prezidentas Janukovičius, ir per 2014 m. kovo mèn. Rusijos Krymo aneksiją Merkel padare keletą griežtų pareiškimų, kurie kitose Europos valstybių sostinèse buvo suprasti kaip ženklas, kad Vokietija yra pasiruošusi lyderiauti ${ }^{17}$. Rusijos valstybinè žiniasklaida Vokietijos paramą Euromaidanui greitai panaudojo savo tikslams ir pateikè jo lyderius šalies auditorijai kaip fašistus ir nevengė lyginti rusų likimo Ukrainoje su žydų likimu nacistinèje Vokietijoje.

Berlynas buvo itin sukrèstas, kai $2014 \mathrm{~m}$. kovo mèn. Rusija aneksavo Krymą. Aneksuodama Krymą, Rusija visiškai atmete po Šaltojo karo pasiektą susitarimą, pagrịstą pagarba nacionaliniam suverenumui ir demokratiniam procesui, taip grịždama prie XIX amžiaus politikos, kai teritorijos buvo užkariaujamos panaudojant jègą. Merkel nedelsdama sureagavo ir pasmerkẻ aneksiją kaip neteisètą, o vèliau netgi apibūdino ją kaip „nusikalstamą “18. Ragindama persvarstyti Vokietijos ir ES energetinès priklausomybès nuo Rusijos

\footnotetext{
${ }^{16}$ Buvo ịtrauktas naujas straipsnis ị vokiečių k. žodyną su anatraštiniu žodžiu „merkeln“, reiškiančiu nesugebejimą priimti sprendimo ar pareikšti savo nuomonės, žr. http://www.politico.eu/article/wordsyoung-germans-just-merkeln-dictionary-jugendwort-smombie/.

${ }^{17} \mathrm{http} / / /$ www.kiew.diplo.de/Vertretung/kiew/de/08/03_Politik/Merkel_2401.html.

${ }^{18} \mathrm{http}$ ://www.faz.net/aktuell/politik/70-jahre-kriegsende/gedenken-in-moskau-merkel-nennt-annexionder-krim-verbrecherisch-13585275.html.
} 
strategiją ir palaikydama tolesnes sankcijas (taip rizikuodama prarasti pagrindinę Vokietijos pramonés paramą), ji sieke dialogo ir bendradarbiavimo ${ }^{19}$. Merkel kalbėjosi su Putinu beveik kasdien stiprejjant Ukrainos krizei ir netgi po to, kai Rusijos lyderis pasiuntè kariuomenę į Krymą.

Ir tik 2014 m. liepos mèn. numušus Malaizijos civilinị orlaivị MH17, vis labiau nusivilianti Vokietija ėmè smerkti Rusiją jau ne vien žodžiais. Nors pati ir nepalaikè griežtų sankcijų, ji èmėsi aiškios lyderystės, konsoliduodama bendrąją sankcijų politiką ${ }^{20}$. Visgi Berlynas nuolatos primindavo savo partneriams, kad durys ị taikų sprendimą turi būti laikomos atviros ir negalima leisti, kad emocijos valdytu politiką ${ }^{21}$. Vokietija taip pat rimtai èmèsi tarpininkès vaidmens kartu su Prancūzija dèl Antrojo Minsko susitarimo nutraukti ugni netgi tada, kai kitos valstybès buvo beprarandančios tikejjimą šiuo procesu.

Berlynas taip norejjo išvengti eskalavimo, kad ir labai pasipiktinęs, jis aiškiai atmetė bet kokias istorines paraleles. Kai kurie Vokietijos apžvalgininkai pabrèžè ironiją to, kad Krymo aneksija įvyko pagal tokị modelį, kuriuo nacistinė Vokietija 1938 m. aneksavo Sudetų kraštą 22 . Bet kai Vokietijos finansų ministras Wolfgangas Schäuble (dèl savo amžiaus ir reputacijos atviriausiai pasisakantis vyriausybès narys) viešai pabrèžè tokią analogiją su Sudetų kraštu, reakcija šalyje buvo negailestinga ${ }^{23}$. Netgi netiesioginis Rusijos lyderio palyginimas su Adolfu Hitleriu atrodè per drąsus. Nors Merkel ir nepeikè savo ministro, tačiau nedelsdama nuo jo atsiribojo, pareikšdama, kad Krymo aneksija vis dèlto buvo sui generis atvejis.

Krymo palyginimas su Sudetu kraštu parodè, koks jautrus klausimas yra Vokietijos ir Rusijos santykiai Vokietijos vidaus polemikoje. Netgi beveik visai politinei klasei pasmerkus Krymo aneksiją, išliko stiprus pasipriešinimas nuostatai konfrontuoti su Rusija. Opozicija kyla ne vien tik iš politinio spektro kraštutinių kairiųjų kaip Die Linke partijos, susikūrusios iš buvusios Rytų Vokietijos komunistų, kurie tebèra nusiteikę prieš Ameriką ir NATO. Kai kurie socialdemokratai kaip buvę kancleriai Gerhardas Schröderis ir Helmutas Schmidtas taip pat yra pasmerkę griežtą poziciją Rusijos atžvilgiu ${ }^{24}$. Šie inte-

\footnotetext{
${ }^{19}$ https://www.bundestag.de/dokumente/textarchiv/2014/49865952_kw11_de_regierungserklaerung_ ukraine/216288.

${ }^{20}$ ECFR foreign policy scorecard 2015, www.ecfr.eu/scorecard/2015.

${ }^{21}$ Walter Steinmeier: "Wut und Empörung dürfen in der Ukraine-Krise nicht das letzte Wort sein" Frankfurter Allgemeine Sonntagszeitung, 3.8.2014.

${ }^{22}$ Sudetai - tai dalis Čekoslovakijos, turinčios bendrą sieną su Vokietija, su etnine vokiečių dauguma iki jų išstūmimo 1947 m. Nacistinė Vokietija aneksavo Sudetų kraštą 1938 m. Čekoslovakijos valdžios tariamos vykdomos etninių vokiečių priespaudos.

23 “Ärger um Schäuble: Merkel distanziert sich von Putin-Hitler-Vergleich”, Der Spiegel, 31.3.2014.

${ }^{24}$ http://www.zeit.de/politik/2014-03/schmidt-krim-putin.
} 
ligentijos atstovai, kurie rodo simpatiją Rusijai ir Putinui, dažnai yra apibūdinami gana sarkastišku terminu Russlandversteher (tie, kurie supranta Rusiją, arba Rusijos garbintojai). Tačiau anaiptol ne visi Russlandversteher yra tik kairieji - kraštutinèje dešinèje tam tikrą pritarimą Putinui reiškia populistinè Alternative für Deutschland (AfD) partija, o kai kurių stambių Vokietijos kompanijų valdybų nariai daro didelį spaudimą, kad nebūtų ịvestos sankcijos Rusijai $^{25}$. Kita vertus, Žaliųjų partija, nepaisant jos pacifistinių ištakų, pritaria griežtesnei pozicijai Maskvos atžvilgiu.

Kaip socialdemokratas ir buvęs tuomečio kanclerio Schröderio protežè užsienio reikalų ministras Frankas-Walteris Steinmeieris politiškai irgi buvo artimesnis Russlandversteher. Tačiau Putino tiesmukas ir nediplomatiškas elgesys krizès metu leido Steinmeieriui, o vèliau ir Merkel, atsikratyti susilaikymo, kadangi bet kokie mėginimai atgaivinti didesne bendradarbiavimo dvasia pasižymintị aštuntojo XX a. dešimtmečio Rytų politikos požiūrị, dabartiniame kontekste būtų atrodę naivūs ir galintys sumenkinti Vokietijos autoritetą jos partnerių akyse.

Padarius prielaidą, jog dauguma šalių vertina santykius su Rusija, remdamosios savo istorine patirtimi ir interesais, Vokietija nesiskiria nuo visų kitų ES šalių narių. Ypatingas Vokietijos ir Rusijos santykių jautrumas gali paaiškinti, kodèl nuo pat pradžiu Vokietija elgèsi atsargiai ir užėmè dviprasmišką poziciją. Jungtinei Karalystei, Lenkijai, Baltijos ir Skandinavijos valstybėms laikantis gana amerikietiško konfrontacinio požiūrio, daugelis Pietų ir Pietryčių Europos šalių narių dẻl ekonominių priežasčių arba baimindamosi, kad nenutrūktų energijos tiekimas, nenorèjo, kad santykiai su Rusija komplikuotųsi dèl Ukrainos. Kyla klausimas, kaip gali turèti 28 atskiros valstybès bendrą poziciją? Štai čia ir iškyla lyderystès klausimas.

\section{Ukrainos krizès įtaka vadovaujamam Vokietijos vaidmeniui ES}

2014 m. sausio mèn., vykstant Euromaidano įvykiams, Miuncheno saugumo konferencijos metu Vokietijos prezidentas Joachimas Gauckas pareiškè, kad reikalinga nauja Vokietijos užsienio politikos strategija, kuri būtų pagrịsta aktyvesniu dalyvavimu tarptautineje arenoje tuo pat metu išlikdama bendros ES politikos dalimi. Nors kaip prezidentas Gauckas atlieka tik formalu vaidmeni, jo kalba sukèlè pokariu gimusių Vokietijos politikų susierzini-

${ }^{25} \mathrm{http} / / /$ www.zeit.de/politik/2014-03/schmidt-krim-putin. 
mą. Kai kurie vyriausybès ministrai, ịskaitant ir užsienio reikalų ministrą Steinmeierị, atvirai pritarè Gauckui, nors tai galejo būti suprasta kaip atviras iššūkis kanclerei. Faktiškai, šis pareiškimas turèjo būti signalas ne tik Vokietijos partneriams Europoje. Jis turèjo būti įspejjamas ir Merkel, kuriai aiškiai trūko ryžto ir ne tik užsienio politikos reikaluose ${ }^{26}$. Pasak Gaucko (kuris savo inauguracinejje kalboje gynè vokiškąją karinio santūrumo kultūrą), Vokietija turètų atsikratyti savo ịpročio nusigręžti, susidūrusi su tarptautine krize ${ }^{27}$.

Šalyje atsiradęs noras, kad Vokietija aktyviau veiktų, sutapo su akivaizdžiu politinès lyderystès nebuvimu ne tik Europos Sąungos bendroje užsienio ir saugumo, bet ir viso pasaulio politikoje. Issipainiojusios it savo vidaus problemas, JAV nebuvo pasiruošusios imtis vadovaujamo vaidmens pasaulio politikoje. Priešingai nei Bushas, Barackas Obama nejautė ypatingos JAV atsakomybès dèl Europos. Jis tikejjosi, kad europiečiai patys imsis vadovaujamo vaidmens, kilus krizèms jų pačių žemyne. Tačiau kadangi ES valstybès negebèjo kalbėti vienu balsu, ES institucijos irgi nesugebejo imtis jokio vadovaujamo vaidmens. Kitos dvi potencialios Europos lyderès Jungtinė Karalystė ir Prancūzija irgi buvo per daug îsivèlusios ị savo vidaus problemas - Jungtinè Karalystè patyrè dvigubą identiteto krizę, kurią išryškino referendumas Škotijoje, o Prancūzija beveik nuolat turejjo ekonominių ir politinių bėdų.

Krymo aneksija buvo iššūkis Vokietijos užsienio politikai keliais atžvilgiais. Viena vertus, Vokietija tvirtai remia bendrą ES užsienio politiką, kadangi ES kaip ir Vokietija tarptautiniuose santykiuose nuosekliai teikia pirmenybę normoms ir taisyklèms, o ne jëgai. Kita vertus, Vokietijos ir Rusijos santykiai buvo reikšmingi Vokietijai ne tik ekonomine, bet ir politine prasme, kaip Berlyno reikšmingumo šaltinis ES ir NATO kontekste ${ }^{28}$. Iškilus sunkumams dèl šių Vokietijos užsienio politikos aspektų, o taip pat dẻl JAV pozicijos remti Europą, bet nesiimti vadovaujamo vaidmens, visų akys nukrypo ị Berlyną, iš kurio buvo laukiama Europos Sąjungos atsako koordinavimo.

Vis dèlto tik 2014 m. liepos mėn., numušus orlaivị MH17 (labai tikètina, kad tai padarè Rusijos remiami separatistai), Merkel tvirtai èmèsi vaidmens, kurio likusi Europos dalis iš jos tikejjosi. Nors pati Vokietija nepalaikè griežtų sankcijų, ji tapo aiškia lydere, konsoliduodama bendrąą sankcijų politiką antroje $2014 \mathrm{~m}$. puseje $\mathrm{e}^{29}$.

\footnotetext{
${ }^{26}$ Ypač Steinmeierio pirmtakas užsienio reikalų ministro poste Guido Westerwelle buvo tapęs tokios netinkamos politikos simboliu.

${ }^{27}$ Joachim Gauck, inauguration speech at the Munich security conference,

${ }^{28}$ Joseph Janning, "German foreign policy and the EU: Leader by default?", ECFR commentary, 5/2/2015

${ }^{29}$ ECFR foreign policy scorecard 2015, www.ecfr.eu/scorecard/2015.
} 
Tai nebuvo pirmas kartas, kai Berlynas atsidūrè vienas (be Paryžiaus) ES lyderio pozicijoje. Vykstant ekonomikos ir finansų krizei, kuri prasidejjo 2007-2008 m., politinis ES svorio centras iš Briuselio persikèle ị ES valstybių narių sostines. Itin svarbu, kad pagrindinis vaidmuo, kurį atliko Berlynas euro zonos valstybių skolos krizès metu (ir apskritai Vokietijos ekonominės galios atžvilgiu) pastūmèjo Vokietiją tapti ES sprendimų priẻmimo lydere. Kaip ir ekonominės krizès metu, taip ir kilus krizei Ukrainoje, Vokietijai atiteko svarbiausias vaidmuo ES užsienio politikoje, tačiau ne pagal išankstinị sumanymą, bet daugiau dèl atsiradusio lyderystès vakuumo ES ir už jos ribų.

Vokietijos santūrumas užsienio politikoje visada buvo ryškesnis negu kitose politikos srityse. Ir tik palaipsniui, šio amžiaus pradžioje, ji pradejjo veikti užsienio politikoje ir pamažu nustojo vengti lyderiauti ${ }^{30}$, prisiimdama issipareigojimus Kosove ir Afganistane. Tačiau imtis vadovaujamo vaidmens reiške ir prisiimti riziką, kadangi baimè būti apkaltintam hegemonija Berlyne niekuomet neišnyko. Ir tai buvo pagrịsta, kadangi bet kokie vienašališki veiksmai Maskvos atžvilgiu buvo ịtariai sutinkami naujosiose ES valstybėse narèse. 2006 m. balandžio mėn. Radosławas Sikorskis, tuometis Lenkijos gynybos ministras, palygino Nord Stream dujotiekio tarp Rusijos ir Vokietijos, turëjusio aplenkti Baltijos valstybes ir Lenkiją, projektą su liūdnai pagarsèjusiu $1939 \mathrm{~m}$. Molotovo-Ribentropo paktu tarp Sovietų Sąjungos ir nacistinès Vokietijos ${ }^{31}$.

Tačiau faktiškai, nors ir matydamos Ukrainos konfliktą per savo pačių patirties ir interesų prizmę, daugelis ES valstybių narių dažniausiai derinasi prie Vokietijos pozicijos. Toks neformalus Vokietijos lyderystès pripažinimas yra iš dalies dèl to, jog Berlynas turi ne tik reikiamus diplomatinius pajègumus, bet ir privilegijuotą priejimą prie informacijos, kas labai sustiprina jos autoritetą tarp kitų valstybių partnerių. Tačiau tai vyksta daugiau dèl Vokietijos europietiškosios tapatybès, paprastai suvokiant ją kaip esančią mažiau savanaudišką ir jautresnę mažujų šalių pozicijų atžvilgiu, negu kitos didesnès ES valstybès.

Be to, neformaliojo vadovavimo praktika, kur svarbiausi sprendimai parengiami neformaliuose ES lyderių susitikimuose, prieš oficialiai juos įforminant, o taip pat tvirti Berlyno ir Varšuvos ryšiai padrąsino Vokietijos partnerius pritarti Vokietijos lyderystei, siekiant igyvendinti bendrus ES užsienio politikos siekius - neleisti Maskvai priešintis ES ir NATO plètrai ir taip pat neleisti atgauti kontrolès teritorijose, kurias Putinas tebelaiko artimuoju užsieniu.

\footnotetext{
${ }^{30}$ Jeffery C. and Paterson, W.E. (2003), "Germany and European Integration: A Shifting of Tectonic Plates", West European Politics, vol. 26, no. 4, p. 59-75.

${ }^{31}$ http://www.spiegel.de/wirtschaft/indirekter-hitler-vergleich-polnischer-minister-poltert-gegen-schroeder-und-merkel-a-413931.html.
} 
O žvelgiant iš Rusijos pusès ir turint omenyje tai, jog Putinas yra užvaldytas statuso ir prestižo manijos, neatrodo, kad Maskva būtų sutikusi derètis iš esmès su ne tokiu svariu tarpininku kaip Vokietija, kadangi ir Prancūzija, ir Jungtinè Karalystė nesugebėjo arba nenorejjo atlikti šio vaidmens. Pagrindinio tarpininko pasirinkimą nulemè ir asmeniniai Merkel ir Putino ryšiai, kurie kalba vienas kito kalbomis. Dar daugiau, Maskva suvokia, jog dèl istorinių aplinkybių ir savo ekonominių interesų Rusijoje, Vokietija nėra linkusi bloginti dvišalių santykių ir dèl to tikriausiai laikysis nuosaikesnès pozicijos. Dèl to galima daryti išvadą, kad aneksuodama Krymą, vykdydama karinę intervenciją Rytų Ukrainoje ir teikdama aiškią pirmenybę dialogui su Berlynu, o ne Briuseliu, pati Rusija netiesiogiai padejjo Vokietijai tapti ES užsienio politikos lydere.

Ką tai reiškia žvelgiant iš Baltijos šalių perspektyvos? Rusijai, kurios ekonominè padètis vis blogejja, jos piliečių gynimas nuo pagal jos suvokimą išorès priešų (ị kuriuos įeina ir Baltijos valstybès) tampa naujuoju legitimumo pagrindu, kuris keičia ankstesnị ekonominès gerovès siekị. Didindamas ịtampą, Putinas gali atitraukti visuomenès pyktị dèl blogẻjančio gyvenimo lygio ir nukreipti ji prieš Vakarus. Nors ir būdamos apsaugotos nuo tiesioginès Rusijos agresijos kaip NATO narès, artimiausios Rusijos kaimynès, Lietuva, Latvija ir Estija yra vienos iš pirmųjų, kurioms lemta patirti politinius ir ekonominius padarinius. Žiūrint iš Vilniaus, Rygos ar Talino perspektyvos, Vokietijos tarpininkavimo ịtaka Rusijai gali atrodyti kaip ryžto trūkumas. Tačiau, bet koks tolesnis eskalavimas tik sustiprintų Putino sistemą, nes tai leistų Kremliui toliau pateisinti vis didejjančius eilinių Rusijos piliečių sunkumus ir tuo pat metu kovoti su opozicija šalies viduje.

\section{Išvados}

Trys viena po kitos sekusios krizès (eurozonos, Ukrainos ir pabėgèlių), kurios vos per keletą metų sukrètė ES, atskleidè rimtus valstybių narių nesutarimus ir leido suabejoti kai kuriomis pagrindinèmis nuostatomis dèl ES vieningumo. Sprendžiant visas tris krizes, Vokietijai atiteko vadovaujamas vaidmuo. Iš pradžiu ji to èmèsi nenoriai, bet vèliau jautėsi vis tvirčiau. Euro krizè parodè, kad realiai reikalinga tvirta lyderyste, ir tokios lyderystès paieškos standartiškai nuvede į Berlyną. Padrąsinta, kad dauguma jos partnerių beveik vien tik teigiamai priima jos naujaji vaidmeni, ir turint omenyje, kad Ukrainos krizès metu vèl reikejjo lyderio, Vokietija tapo tvirtesnè ir užsienio politikos srityje. Prie to labai prisidejjo vis didejjanti Rusijos arogancija ir šiurkštūs pamatinių Europos vertybių ir tarptautinès teisès pažeidimai. 
Žiūrint iš Vilniaus, Rygos ar Talino perspektyvos, galima Vokietijos hegemonijos Europoje grèsmè šiuo metu atrodo geriausias pasirinkimas iš blogiausių. ES nebesipriešinant jo vadovaujamam vaidmeniui, Berlynas pamate, kad jo bandymas perkelti savo užsienio politiką i ES pasiteisino, kadangi tokiu būdu jam pavyko suderinti du dalykus, nes jis ne tik apgynè savo interesus, bet ir sustiprino savo kaip ES normomis ir vertybėmis besivadovaujančios visuomenès įvaizdị.

Šiame kontekste Berlyno vaidmuo sprendžiant trečiąją Europos krizę (2015 m. pabègèlių krizę) gali atrodyti nelogiškas, turint omenyje, kad plačiai atverdama savo sienas musulmonams pabėgèliams iš Sirijos ir kitų karo draskomų regionų, Vokietija rizikavo atstumti savo partnerius Europoje ir pakenkti savo lyderystès pripažinimui. Tačiau atidžiau pažvelgus, Berlyno pozicijoje galima matyti tam tikrą logiką. Pokario Vokietijos politikos erdve šiandien yra platesnè nei bet kada anksčiau, nes jos vadovaujamas vaidmuo dabar pripažịstamas už šalies ribų, o šalyje nèra jokios destruktyvios populistinės opozicijos, kuri būtų pakankamai stipri, kad galètų rimtai pakenkti vyriausybei. Dèl to Berlynas gali leisti sau vykdyti vertybėmis grindžiamą politiką, atveriant savo sienas musulmonams pabejèliams.

Berlynas tikisi, kad trumpalaikis neigiamas poveikis ir tokio veiksmo nepopuliarumas šalyje ir užsienyje, bus nusvertas suvokus politinès lyderystės ir ekonomikos augimo ilgalaikę naudą. Šiandien, kai nacionalizmas, populizmas ir religinis nepakantumas vèl pradeda atsigauti visame pasaulyje, atrodo, jog Vokietijos kaip vertybėmis grindžiamos, atviros ir tolerantiškos šalies reputacija bus daug labiau negu bet kada iki šiol pastebima, ir tai pasitarnaus jos patrauklumui pasaulio rinkose, nes Made in Germany vertybès ir interesai dažniausiai yra linkę susipinti.

Žinoma, Berlynas norètų ir savo pabėgèlių politiką perkelti į ES politiką. Taip būtų pasidalyta atsakomybe. Tačiau dabartinè ES politika yra kitokia. Todèl galiausiai Vokietija gali nebeatlikti vadovaujamo vaidmens, o išcentrinès jègos ES sustiprèti. O tai, atsižvelgiant ị esamas alternatyvas, neatrodo kad būtų tinkama Berlynui, Briuseliui, Vilniui, Rygai ar Talinui.

2015 m. rugpjūčio mèn. 